\title{
Myocardial potency of Caesalpinia bonducella Linn. on doxorubicin induced myocardial infarction in albino rats
}

\author{
Agnel Arul John Nayagam ${ }^{1,2^{*}}$ (D), Shobana Gunasekaran ${ }^{3}$, Sivasubramanian Rangarajan ${ }^{3}$ and Suganya Muthaiah ${ }^{3}$
}

\begin{abstract}
Objective: Caesalpinia bonducella L. is well known and extremely valuable herb in ayurvedic system of medicine. The present study is aimed to design the evaluation of aqueous extract of Caesalpinia bonducella L. on doxorubicin induced myocardial infarction in wistar strains of albino rats of both sex.

Materials and methods: The experimental animals are divided in to 5 groups of 6 animals each. Group I (Normal Control), Group II (Negative Control, $2.5 \mathrm{mg} / \mathrm{kgbw}$ of Doxorubicin i.p.), Group III (2.5 mg/kgbw of Doxorubicin i.p.) + AECB (150 mg/kgbw), Group IV (2.5 mg/kgbw of Doxorubicin i.p.) + AECB (300 mg/kgbw), Group V (2.5 mg/kgbw of Doxorubicin i.p.) + standard drug (Propranolol $5 \mathrm{mg} / \mathrm{kgbw}$ ). Doxorubicin induced myocardial infarction was confirmed by disturbances in levels of cardiac markers (Lactate Dehydrogenase, Troponin-T, Creatine Kinase-MB Isoenzyme, Creatine Phosphokinase), nucleic acid contents (DNA and RNA), Challenged levels of Membrane bound enzymes such as Na+/K + ATPase, Ca2 + ATPase and Mg2 + ATPase, Decreased tissue protein and altered lipid profile markers.
\end{abstract}

Results: Doxorubicin induced rats significantly showed increase in the activities of LDH, CK-MB, CPK, Troponin$T$, nucleic acids, membrane bound enzymes, lipid profiles and decrease in the serum HDL. Treatment with AECB simultaneously at two different doses such as $150 \mathrm{mg} / \mathrm{kg} \mathrm{bw}, 300 \mathrm{mg} / \mathrm{kg}$ bw prevented the leakage of myocardium markers and altered the levels of Protein, DNA, RNA and membrane bound enzymes. The AECB prevented the altered variations in Cholesterol, Triacylglycerols, Phospholipids and Free Fatty Acids. This extract also brought back the levels of Lipoproteins like HDL, LDL and VLDL which were varied in disease control animals.

Conclusion: The present study concludes that AECB is effective in controlling the cardiac markers and lipid levels which could be due to its ability to maintain the membrane stability and repair the myocardial damage.

Keywords: Caesalpinia bonducella L, Myocardial infarction, Doxorubicin, Lactate dehydrogenase, Troponin

\section{Introduction}

Myocardial infarction (MI) is one of the most extensively broadened manifestations of cardiovascular disease, which is primarily coupled with imbalance between coronary blood supply and myocardial demand [1]. MI is a foremost public health concern

\footnotetext{
* Correspondence: aruljohnagnel@gmail.com

${ }^{1}$ Sri Ranga Ramanuja Centre for Advanced Research in Sciences, Srimad Andavan Arts and Science College, Tiruchirappalli, Tamil Nadu 620 005, India ${ }^{2}$ Department of Biochemistry, Srimad Andavan Arts and Science College (Autonomous), Tiruchirappalli, Tamilnadu 620 005, India Full list of author information is available at the end of the article
}

and the leading cause of morbidity and mortality in the Western world and even in China. As yet, morbidity and mortality due to MI have reached epidemic proportions, accounting for 16.7 million deaths/year worldwide [2].Moreover, MI can also cause other obvious symptoms, such as myocardial fibrosis [3] and cardiac hypertrophy [4]. The specific mechanism involving MI have proved to be associated with oxidative stress [5], apoptosis [6], and inflammation [7]. Due to changing lifestyles in developing countries, such as India, and particularly 
in urban areas, MI is making an increasingly important contribution to mortality statistics [8].

Doxorubicin (DOX), a well-known anti-neoplastic drug, and extensively used to treat numerous diseases has been restricted due to the dose-dependent cardio toxicity which may cause myocardial injury [9] It has been calculated that approximately $10 \%$ of patients treated with doxorubicin or its derivatives will develop cardiac complications up to 10 years after the cessation of chemotherapy. The pathogenesis of doxorubicin-induced cardiotoxicity is multifactorial. Oxidative stress is a major cause of doxorubicininduced cardiotoxicity. Doxorubicin-induced heart failure can appear very late after the last administration. There is no explicit curative or precautionary treatment available.

The medicinal plants are potential sources of drugs as they are rich in secondary metabolites and essential oils of therapeutic importance. Uses of medicinal plants in various ailments are due to being economical, effective, their ease availability and due to their safety. World Health Organization (WHO) estimates that $80 \%$ of total world's population presently uses medicines of herbal origin for primary health care [10]. Existing modern drugs are successful in preventing cardiovascular disorders but their use is often limited because of their side effects. Herbal drugs are approved widely, even when their biologically active compounds are unknown, because of their effectiveness, lesser side effects and relatively low cost [11].

Caesalpinia bonducella (L) (Fleming) belonging to the family Caesalpiniaceae and its Tamil name is Kalichikai. It has various medicinal properties. A lot of pharmacological investigations had been carried out based on plant based on the rich active metabolite content. The nuts of Caesalpinia bonducella Linn. has anti-diarrheal activity and their seeds have anti-fertility, antibacterial, antifungal, anti-sposmodic, anti-diabetic,analgesic, anxiolytic, antioxidant and anti-inflammatory activity [12]. The leaves have anti tumor and cardio protective activity. Hence, the present study was undertaken to evaluate the myocardial potency of Caesalpinia bounducella Linn. against doxorubicin induced myocardial infarction in albino rats.

\section{Materials and methods Identification and authentication}

Plant source selected for the present study was Caesalpinia bonducella L. Aerial parts of the selected plant were collected from in and around Trichy, identified with the help of Flora of the Presidency of Madras. The plant was authenticated with the specimen deposited at RAPINAT Herbarium, Department of Botany, St. Joseph's college, Trichy.

\section{Preparation of aqueous plant extract}

The aerial parts of the plant were shade dried and coarsely powdered with electrical blender. $200 \mathrm{~g}$ of dry powder of Caesalpinia bonducella L. was mixed with $1200 \mathrm{ml}$ of water. Then it was boiled until it was reduced to one third and filtered. The filtrate was evaporated to dryness. Paste form of the extract obtained was subjected to pre-clinical screening.

\section{Experimental design}

Wistar strain of albino rats of either sex were divided into five groups, each comprising of six rats. Group 1 was served as Normal control, Group 2 was served as Doxorubicin induced rats $(2.5 \mathrm{mg} / \mathrm{kg}$ bw IP on days 1 , 7, 14, 21, 28), Group 3 was served as Doxorubicin $(2.5 \mathrm{mg} / \mathrm{kg}$ bw IP on days $1,7,14,21,28)+\mathrm{AECB}$ $(150 \mathrm{mg} / \mathrm{kg}$ bw for 28 days) and Group 4 was served as Doxorubicin $(2.5 \mathrm{mg} / \mathrm{kg}$ bw IP on days $1,7,14,21$, $28)+\operatorname{AECB}(300 \mathrm{mg} / \mathrm{kg}$ bw for 28 days), Group 5 was served as Doxorubicin $(2.5 \mathrm{mg} / \mathrm{kg}$ bw IP on days 1,7 ,

Table 1 Effect of aqueous extract of Caesalpinia bonducella L. (AECB) on activities of marker enzymes in serum of experimental animals

\begin{tabular}{|c|c|c|c|c|c|}
\hline Groups & 1 & $\|$ & III & IV & V \\
\hline CPK ( $\mu$ mol of creatine liberated/hr./L) & $\begin{array}{l}0.91 \\
\pm 0.17\end{array}$ & $\begin{array}{l}3.67 \\
\pm 0.22^{*_{a}}\end{array}$ & $\begin{array}{l}2.56 \\
\pm 0.24^{* * * b}\end{array}$ & $\begin{array}{l}1.41 \\
\pm 0.15^{* * b}\end{array}$ & $\begin{array}{l}1.25 \\
\pm 0.11^{*}{ }^{*}\end{array}$ \\
\hline LDH (nm of pyruvate liberated/h/L) & $\begin{array}{l}178.24 \\
\pm 2.42\end{array}$ & $\begin{array}{l}298.34 \\
\pm 3.14^{* a}\end{array}$ & $\begin{array}{l}248.72 \\
\pm 2.71^{* * 6}\end{array}$ & $\begin{array}{l}197.33 \\
\pm 2.45^{* * \mathrm{~b}}\end{array}$ & $\begin{array}{l}188.74 \\
\pm 2.11^{* c}\end{array}$ \\
\hline CK MB (IU/dl) & $\begin{array}{l}33.33 \\
\pm 10.33\end{array}$ & $\begin{array}{l}93.33 \\
\pm 3.56^{*_{a}}\end{array}$ & $\begin{array}{l}116.5 \\
\pm 6.86^{* * b}\end{array}$ & $\begin{array}{l}63 \\
\pm 6.26^{* * b}\end{array}$ & $\begin{array}{l}49 \\
\pm 3.99^{*} \mathrm{c}\end{array}$ \\
\hline Troponin (mg/dl) & $\begin{array}{l}0.52 \\
\pm 0.07\end{array}$ & $\begin{array}{l}1.80 \\
\pm 0.07^{* a}\end{array}$ & $\begin{array}{l}1.38 \\
\pm 0.06^{* * b}\end{array}$ & $\begin{array}{l}0.79 \\
\pm 0.06^{* * b}\end{array}$ & $\begin{array}{l}0.7 \\
\pm 0.06^{*}{ }^{\circ}\end{array}$ \\
\hline
\end{tabular}

Values are mean \pm S.E.M $(n=6)$

${ }^{{ }^{*}} P<0.05$ statistically significant when disease control(Group II) compared with normal control (Group I), ${ }_{{ }^{* * *}} P<0.05$ statistically significant when AECB treated (Group III,IV) compared with disease control groups(group II), ${ }^{{ }^{*}} P<0.05$ statistically significant when AECB treated (Group III,IV) compared with standard drug treated(Group V) 
Table 2 Effect of aqueous extract of Caesalpinia bonducella L. on tissue protein in experimental animals

\begin{tabular}{|c|c|c|c|c|c|}
\hline Groups & I & $\|$ & III & IV & V \\
\hline Tissue protein (mg/g tissue) & $32.75 \pm 3.35$ & $39.88 \pm 9.70^{a^{*}}$ & $36.33 \pm 11.51^{b^{* *}}$ & $19.93 \pm 6.41^{b^{* *}}$ & $14.81 \pm 6.16^{c^{*}}$ \\
\hline
\end{tabular}

14, 21, 28) + Propranolol (Standard Drug) $5 \mathrm{mg} / \mathrm{kg}$ bw for 28 days).

\section{Induction of myocardial infarction}

Myocardial infarction was induced by doxorubicin $(2.5 \mathrm{mg} / \mathrm{kg} \mathrm{bw})$ intra peritonial injection to the animals.

\section{Statistical analysis}

All the results were expressed as mean \pm S.E. The data were statistically analyzed by one-way analysis of variance (ANOVA) and $P$ values $<0.05$ were considered as significant.

\section{Parameters studied}

After the experimental period, the blood, serum and heart were collected which are used for biochemical estimations of Cardiac markers like Creatine Phospho Kinase [13] (CPK), Lactate dehydrogenase [14] (LDH), CK MB [15], Troponin [16] and biochemical parameters like Protein [17], nucleic acid like Deoxy Ribo Nucleic Acid [18] (DNA), Ribo Nucleic Acid [19] (RNA) and lipid profile like Total cholesterol [20], Triglycerides [21], Phospholipid [22], Free fatty acid [23] and Serum lipoprotein like High Density Lipoprotein [24] (HDL), Low Density Lipoprotein [24] (LDL), Very Low Density Lipoprotein [24] (VLDL) and membrane bound Enzymes like $\mathrm{Na}^{+/} \mathrm{K}^{+}$ ATPase [25], $\mathrm{Mg}^{2+}$ ATPase [26], $\mathrm{Ca}^{2+}$ ATPase [27].

\section{Result and discussion}

The levels of serum marker enzymes in all groups are given in Table 1. Doxorubicin administration significantly increases the serum levels CK, LDH, CK-MB and troponin in group II animals. Administration of aqueous extract of Caesalpinia bonducella Linn. significantly restores the marker level towards normal in group III and IV in dose dependent manner. Group
$\mathrm{V}$ animals did not show any marked variation in the serum marker enzymes level.

The myocardium is rich in enzymes which are required for its metabolic activity. These cardiac markers are measured to evaluate the function of heart. The important enzymes such as serum LDH, $\mathrm{CK}, \mathrm{CK}-\mathrm{MB}$ and the proteins such as troponins, myoglobins are considered as gold standard diagnostic marker of myocardial injury [28]. From the data of results obtained the administration of doxorubicin increased the levels of cardiac markers in the serum. It may indicate the doxorubicin induced cardiac myocytes damage. Compared to animals administered only with doxorubicin, animals treated with AECB in a dose dependent manner restored the levels of cardiac markers such as troponin-T, CPK, $\mathrm{CK}-\mathrm{MB}$ and $\mathrm{LDH}$, which indicates the ability of the extract to reduce leakages of these enzymes from cardiomyocytes.

Total protein level in heart homogenate was significantly decreased in doxorubicin induced animals (group II) compared to normal (group I). Treatment with AECB (group III \& IV) animals showed significant increase in total protein level compared to doxorubicin group. The group $\mathrm{V}$ animals did not show any marked variation in the protein level (Table 2).

In doxorubicin induced myocardial infarcted rats, the decreased level of protein confirmed the onset of myocardial necrosis which may be due to the consequence of cellular injury by excessive free radicals formations [29]. The plant drug treated animals show significantly near normal levels of protein which might be due to the prevention of tissue damage by the plant extract.

The results obtained (Table 3) clearly indicates a significant increase in DNA and RNA level in

Table 3 Effect of aqueous extract of Caesalpinia bonducella L. on DNA and RNA in experimental animals

\begin{tabular}{llllll}
\hline Groups & I & $\|$ & $\| 1$ & IV & V \\
\hline $\begin{array}{l}\text { DNA } \\
\text { (mg/g tissue) }\end{array}$ & $47.29 \pm 2.77$ & $26.59 \pm 3.65^{a^{*}}$ & $25.59 \pm 3.47^{b^{* *}}$ & $26.88 \pm 1.76^{b^{* *}}$ & $16.60 \pm 1.48^{c^{*}}$ \\
$\begin{array}{l}\text { RNA } \\
\text { (mg/g tissue) }\end{array}$ & $27.45 \pm 3.21$ & $16.18 \pm 2.50^{a^{*}}$ & $13.80 \pm 0.67^{b^{* *}}$ & $18.38 \pm 1.75^{b^{* *}}$ & $9.79 \pm 0.53^{c^{*}}$
\end{tabular}

Values are mean \pm S.E.M $(n=6)$

${ }^{a^{*}} P<0.05$ statistically significant when disease control(Group II) compared with normal control (Group I), ${ }^{\text {b** }} P<0.05$ statistically significant when AECB treated (Group III,IV) compared with disease control groups(group II), ${ }^{*} P<0.05$ statistically significant when AECB treated (Group III,IV) compared with standard drug treated(Group V) 
Table 4 Effect of aqueous extract of Caesalpinia bonducella L. on tissue lipid profile in experimental animals

\begin{tabular}{llllll}
\hline Groups & $\mathrm{I}$ & II & III & IV & V \\
\hline Cholesterol (mg/g wet tissue) & $3.63 \pm 0.10$ & $6.34 \pm 0.13^{\mathrm{a}^{*}}$ & $4.47 \pm 0.29^{\mathrm{b}^{* *}}$ & $4.0 \pm 0.04^{\mathrm{b}^{* *}}$ & $3.89 \pm 0.06^{\mathrm{c}^{*}}$ \\
Triglycerides (mg/g wet tissue) & $3.5 \pm 0.27$ & $6.64 \pm 0.17^{\mathrm{a}^{*}}$ & $5.25 \pm 0.05^{\mathrm{b}^{* *}}$ & $4.27 \pm 0.06^{\mathrm{b}^{* *}}$ & $3.99 \pm 0.06^{\mathrm{c}^{*}}$ \\
Phospholipids (mg/g wet tissue) & $12.42 \pm 1.48$ & $7.11 \pm 1.35^{\mathrm{a}^{*}}$ & $9.72 \pm 0.87^{\mathrm{b}^{* *}}$ & $11.88 \pm 0.799^{\mathrm{b}^{* *}}$ & $12.08 \pm 1.11 \mathrm{c}^{*}$ \\
Free fatty acid (mg/g wet tissue) & $5.57 \pm 0.25$ & $8.58 \pm 0.18^{\mathrm{a}^{*}}$ & $7.14 \pm 0.06^{\mathrm{b}^{* *}}$ & $6.15 \pm 0.05^{\mathrm{b}^{* *}}$ & $6.04 \pm 0.06^{\mathrm{c}^{*}}$ \\
\hline
\end{tabular}

Values are mean \pm S.E.M $(n=6)$

$\mathrm{a}^{*} P<0.05$ statistically significant when disease control(Group II) compared with normal control (Group I), ${ }^{\mathrm{b}^{* *}} P<0.05$ statistically significant when AECB treated (Group III,IV) compared with disease control groups(group II), ${ }^{\mathrm{C}^{*}} \mathrm{P}<0.05$ statistically significant when AECB treated (Group III,IV) compared with standard drug treated(Group V)

doxorubicin treated animals. The animals were treated with plant extract (Group III \& IV) showed the decreased levels of DNA and RNA compared to disease control. The group $\mathrm{V}$ animals did not show any marked variation.

Increase in DNA and RNA content during myocardial infarction have already been reported. The increased DNA content in doxorubicin induced rats are probably attributable to fibroblast cells since cardiac muscle cells don't undergo mitotic division. The RNA synthesis could be a primary event in myocardial infarction and leads to hypertrophy at a later phase and this might be attributed to repair the process stimulated after cellular necrosis in doxorubicin administered animals. The observed restoration of nucleic acids in AECB treated animals indicates the protective efficacy which may be due to reduced synthesis of cellular DNA and RNA.

The results obtained (Table 4) clearly indicates the significant increase in tissue cholesterol, TG, free fatty acid and decreased phospholipid in doxorubicin induced rats (group II). The animals were treated with the plant extract (group III \& IV) showed a decrease in tissue cholesterol, TG and free fatty acid and increase in phospholipid compared with doxorubicin induced rats. The group $\mathrm{V}$ animals did not show any marked variation.

The results obtained (Table 5) clearly indicate a significant increase in serum cholesterol, TG, phospholipid and free fatty acid in doxorubicin induced rats (group II). The animals were treated with the plant extract (group III \& IV) showed a decrease in serum cholesterol, TG, phospholipid and free fatty acid compared with doxorubicin induced rats. The group $\mathrm{V}$ animals did not show any differences.

Lipids play an important role in cardiovascular disease by the way of hyperlipidemia and there by modifying the cellular membrane structure, composition and stability [30]. Doxorubicin induces free radical formation which may cause cholesterol accumulation by increasing cholesterol biosynthesis, by decreased cholesterol ester hydrolysis and thereby reducing cholesterol efflux. Doxorubicin induction causes hyperlipidemia and increased LDL cholesterol in blood which in turn leads to the accumulation of circulating cholesterol at a high level in tissues. In the present study the plant extract restored cholesterol level neared normalcy there by reducing the risk of cardiovascular disease.

Myocardial ischemic rats had increased TG level in tissue and serum were observed which might be due to the increased mobilization of lipids from adipose tissue. The significant increase in TG level in heart might be due to decreased activity of lipoprotein lipase, resulting in decreased uptake of triglycerides from the circulation. In the present study, the TG levels of the plant extract treated groups were significantly reduced and that might be due to heathy cardiomyocyte.

The increased serum free fatty acid level in doxorubicin treated animals may be due to the increased peroxidation of membrane lipids via phospholipase A2 and

Table 5 Effect of aqueous extract of Caesalpinia bonducella L. on activities of lipid profile in serum of experimental animals

\begin{tabular}{|c|c|c|c|c|c|}
\hline Groups & I & $\|$ & III & IV & V \\
\hline Cholesterol (mg/dl) & $90.17 \pm 10.38$ & $197.17 \pm 9.17^{a^{*}}$ & $155.83 \pm 5.32^{b^{* *}}$ & $111.5 \pm 6.12^{b^{* *}}$ & $104 \pm 5.65^{c^{*}}$ \\
\hline Triglycerides (mg/dl) & $65.05 \pm 0.38$ & $185.13 \pm 1.21 \mathrm{a}^{\mathrm{a}^{*}}$ & $110.69 \pm 3.69^{b^{* *}}$ & $75.72 \pm 1.63^{b^{* *}}$ & $70.18 \pm 0.92^{c^{*}}$ \\
\hline Phospholipids (mg/dl) & $8.79 \pm 0.64$ & $14.17 \pm 0.22^{a^{*}}$ & $11.97 \pm 0.77^{b^{* *}}$ & $9.22 \pm 0.17^{b^{* *}}$ & $9.13 \pm 0.12 \mathrm{c}^{*}$ \\
\hline Free fatty acid (mg/dl) & $42.52 \pm 2.56$ & $75.97 \pm 2.01^{a^{*}}$ & $61.35 \pm 0.79^{b^{* *}}$ & $48.99 \pm 1.21^{b^{* *}}$ & $47.07 \pm 0.90^{c^{*}}$ \\
\hline
\end{tabular}

Values are mean \pm S.E.M $(n=6)$

${ }^{a^{*}} P<0.05$ statistically significant when disease control(Group II) compared with normal control (Group I), ${ }^{\text {b** }} P<0.05$ statistically significant when AECB treated (Group III,IV) compared with disease control groups(group II), ${ }^{{ }^{*}} P<0.05$ statistically significant when AECB treated (Group III,IV) compared with standard drug treated(Group V) 
Table 6 Effect of aqueous extract of Caesalpinia bonducella L. on activities of lipoprotein in serum of experimental animals

\begin{tabular}{llllll}
\hline Groups & I & I & III & IV & V \\
\hline HDL (mg/dl) & $24.97 \pm 0.51$ & $9.52 \pm 0.29^{a^{*}}$ & $14.85 \pm 0.38^{b^{* *}}$ & $21.99 \pm 0.46^{b^{* *}}$ & $23.38 \pm 0.41^{c^{*}}$ \\
LDL (mg/dl) & $55.56 \pm 0.71$ & $161.99 \pm 0.70^{a^{*}}$ & $107.91 \pm 1.41^{b^{* *}}$ & $60.93 \pm 1.34^{b^{* *}}$ & $58.41 \pm 0.75^{c^{*}}$ \\
VLDL (mg/dl) & $18.56 \pm 0.29$ & $62.42 \pm 0.31^{a^{*}}$ & $45.09 \pm 0.12^{b^{* *}}$ & $23.42 \pm 0.14^{b^{* *}}$ & $22.38 \pm 0.15^{c^{*}}$ \\
\hline
\end{tabular}

Values are mean \pm S.E.M $(n=6)$

${ }_{\mathrm{a}^{*} P} P<0.05$ statistically significant when disease control(Group II) compared with normal control (Group I), ${ }^{\text {,**}} P<0.05$ statistically significant when AECB treated (Group III,IV) compared with disease control groups(group II), ${ }^{C^{*}} P<0.05$ statistically significant when AECB treated (Group III,IV) compared with standard drug treated(Group V)

also due to the increased lipolysis in adipose tissue. In the plant treated animals, the levels of Free Fatty Acids were significantly restored which indicates the potential of the plant extract to prevents the peroxidation of membrane lipids .

Cell membranes are rich source of phospholipids. The degradation of phospholipid results in membrane dysfunction which leads to cell injury. In the present study, doxorubicin treated animals showed the increased levels of phospholipids which may be due to the free radicals mediated peroxidation of membrane phospholipids and consequent changes in membrane permeability which results in the leakages of phospholipids into the blood. In the present study plant treated animals, the phospholipids were significantly near to normal level which indicate the plant has cardio-protective activity.

The results obtained (Table 6) clearly indicate a significant decrease in serum HDL and increase in LDL, VLDL in the doxorubicin induced animals (group II). Treatment with plant extract (group III, IV) showed an increase in serum HDL and decrease in LDL, VLDL level. Group V animals did not show any marked variation in the serum lipoprotein level.

Doxorubicin induction causes peroxidation of lipids that leads to the membrane damage of myocytes which is evidenced by the increased level of LDL and VLDL and also a fall in HDL. The reduced level of HDL is attributed to the increased triglycerides and cholesterol, since triglycerides and cholesterol were transported from peripheral tissues to the liver for the catabolism and excretion process. In the present study plant extract treated groups shows an increased HDL cholesterol and decreasing LDL and VLDL level which is an indication that myocardial membrane is intact and not damaged by the deleterious effect of doxorubicin and lipid lowering effect of Caesalpinia bonducella L.

The results obtained (Table 7) clearly indicate a significant decrease in tissue $\mathrm{Na}^{+}-\mathrm{K}^{+}$ATPase and $\mathrm{Mg}^{2+}$ ATPase and increase in $\mathrm{Ca}^{2+}$ ATPase in the doxorubicin induced animals (group II). Treatment with plant extract (group III, IV) showed a increase in tissue $\mathrm{Na}^{+}-\mathrm{K}^{+}$ ATPase and $\mathrm{Mg}^{2+}$ ATPase and decrease in $\mathrm{Ca}^{2+}$ ATPase. Group V animals did not show any marked variation in the serum lipoprotein level.

Doxorubicin induced mitochondrial injury is critical to the heart because it would have extremely adverse effects on the contracting functioning of the cardiac myocytes. Membrane bound ATPase such as $\mathrm{Na}^{+} / \mathrm{K}^{+}, \mathrm{Ca}^{2+}$ and $\mathrm{Mg}^{2+}$ of cardiac cells play a significant role in contraction and relaxation cycles of cardiac muscle by maintain normal ion levels within the myocytes [31]. From the Table 7, it was evidenced that the levels of membrane bound enzyme $\mathrm{Na}^{+} / \mathrm{K}^{+}, \mathrm{Ca}^{2+}$ and $\mathrm{Mg}^{2+}$ ATPase is challenged in the doxorubicin alone treated animals which may be due to the lethal myocardial cellular injury. The restoration of these enzymes to near normalcy in AECB treated rats is an indicator of membrane stabilizing protective effect of the plant under study.

\section{Conclusion}

Based on present findings, Caesalpinia bonducella L. protects cardiac muscle from the Doxorubicin induced

Table 7 Effect of aqueous extract of Caesalpinia bonducella L. on activities of membrane bound enzymes in heart of experimental animals

\begin{tabular}{|c|c|c|c|c|c|}
\hline Groups & I & $\|$ & III & IV & V \\
\hline $\begin{array}{l}\mathrm{Na}^{+}-\mathrm{K}^{+} \text {ATPase } \\
(\mu \mathrm{m} \text { of pi liberated/mg protein) }\end{array}$ & $\begin{array}{l}7.87 \\
\pm 0.65\end{array}$ & $\begin{array}{l}1.13 \\
\pm 0.33 a^{*}\end{array}$ & $\begin{array}{l}4.75 \\
\pm 0.36\end{array}$ & $\begin{array}{l}7.18 \\
\pm 0.89 b^{* *}\end{array}$ & $\begin{array}{l}7.38 \\
\pm 0.14\end{array}$ \\
\hline $\begin{array}{l}\mathrm{Mg}^{2+} \text { ATPase } \\
\text { ( } \mu \mathrm{m} \text { of pi liberated/mg protein) }\end{array}$ & $\begin{array}{l}6.27 \\
\pm 0.33\end{array}$ & $\begin{array}{l}0.38 \\
\pm 0.20 a^{*}\end{array}$ & $\begin{array}{l}3.63 \\
\pm 0.34\end{array}$ & $\begin{array}{l}6.11 \\
\pm 0.78\end{array}$ & $\begin{array}{l}6.08 \\
\pm 0.11 c^{*}\end{array}$ \\
\hline $\begin{array}{l}\mathrm{Ca}^{2+} \text { ATPase } \\
\text { ( } \mu \mathrm{m} \text { of pi liberated/mg protein) }\end{array}$ & $\begin{array}{l}1.8 \\
\pm 0.95\end{array}$ & $\begin{array}{l}3.95 \\
\pm 0.33\end{array}$ & $\begin{array}{l}2.95 \\
\pm 0.27\end{array}$ & $\begin{array}{l}1.73 \\
\pm 0.68\end{array}$ & $\begin{array}{l}1.61 \\
\pm 0.13\end{array}$ \\
\hline
\end{tabular}

Values are mean \pm S.E.M $(n=6)$

${ }^{a^{*}} P<0.05$ statistically significant when disease control(Group II) compared with normal control (Group I), ${ }^{\text {b** }} P<0.05$ statistically significant when AECB treated (Group III,IV) compared with disease control groups(group II), ${ }^{*} P<0.05$ statistically significant when AECB treated (Group III,IV) compared with standard drug treated(Group V) 
membrane phospholipid damage and altered lipid profile via lipid peroxidation and helps in maintaining the myocardial cell membrane integrity and function thereby protecting the cells from rupture and preventing leakage of the cardiac markers and lipids. In future, the major active constituents will be isolated for understanding the complete mechanism of cardioprotective action of Caesalpinia bonducella $\mathrm{L}$.

\section{Abbreviations \\ AECB: Aqueous Extract of Caesalpinia bonducella; ATP: Adenosine tri phosphate; CK MB: Creatine Kinase - Muscle / Brain; CK: Creatine Kinase; CPK: Creatine phospho kinase; DNA: Deoxy ribo Nucleic Acid; HDL: High Density Lipoprotein; LDH: Lactate dehydrogenase; LDL: Low Density Lipoprotein; RNA: Ribo Nucleic Acid; TG: Triglycerides; VLDL: Very Low Density Lipoprotein}

\section{Acknowledgements}

The authors are thankful to Management, Srimad Andavan Arts and Science College (Autonoumous) for providing research facilities and Dr.G.Jothi, Dean of Life-Science and Head and Teaching and Nonteaching Faculty of Department of Biochemistry, Srimad Andavan Arts and Science College (Autonoumous), Triuchirappalli, Tamil Nadu, India. For giving guidance to.

complete this research work

\section{Authors' contributions}

SM collected the plant material, prepared plan of work and carried out research work. SG and RS discussed the plan of work with IAEC members and got approval to carry out this research work. AAJN guided the researcher and helped for writing manuscript. All authors read and approved the final manuscript.

\section{Funding}

The study was done through self finance.

\section{Availability of data and materials}

Not Applicable.

\section{Ethics approval and consent to participate}

The study protocol was approved by the ethical guidelines of CPCSEA after obtaining necessary.

clearance from the committee (Approval No: 790/03/ac/CPCSEA).

\section{Consent for publication}

The authors permitted to publish this work in Clinical Phytoscience.

\section{Competing interests}

The authors declare that there is no conflict of interests regarding the publication of this paper.

\section{Author details}

'Sri Ranga Ramanuja Centre for Advanced Research in Sciences, Srimad Andavan Arts and Science College, Tiruchirappalli, Tamil Nadu 620 005, India. ${ }^{2}$ Department of Biochemistry, Srimad Andavan Arts and Science College (Autonomous), Tiruchirappalli, Tamilnadu 620 005, India. ${ }^{3}$ PG \& Research Department of Biochemistry, Srimad Andavan Arts and Science College, Tiruchirappalli, Tamil Nadu 620 005, India.

Received: 13 May 2019 Accepted: 11 December 2019 Published online: 18 December 2019

\section{References}

1. Awada HK, Johnson NR, Wang Y. Sequential delivery of angiogenic growth factors improves revascularization and heart function after myocardial infarction. J Control Release. 2015:207:7-17.

2. Meena B, Anbu Rajan L, Anandan R. Protective effect of betaine on protein, glycoproteins and amino acids in isoprenaline-induced myocardial infarction in albino rats. Biomed Prev Nutr. 2014;4:403-9.
3. Chen SW, Tung YC, Jung SM, Chu Y, Lin PJ, Kao WW. Lumican-null mice are susceptible to aging and isoproterenol-induced myocardial fibrosis. Biochem Biophys Res Commun. 2017:482:1304-11.

4. Nagoor Meeran MF, Jagadeesh GS, Selvaraj P. Thymol attenuates altered lipid metabolism in $\beta$-adrenergic agonist induced myocardial infarcted rats by inhibiting tachycardia, altered electrocardiogram, apoptosis and cardiac hypertrophy. J Funct Foods. 2015;14:51-62.

5. Tang YN, He XC, Ye M, Huang H, Chen HL, Peng WL. Cardioprotective effect of total saponins from three medicinal species of Dioscorea against isoprenalineinduced myocardial ischemia. J Ethnopharmacol. 2015;175:451-5.

6. Suchal K, Malik S, Gamad N, Malhotra RK, Goyal SN, Bhatia J. Kampeferol protects against oxidative stress and apoptotic damage in experimental model of isoproterenol-induced cardiac toxicity in rats. Phytomedicine. 2016;23:1401-8.

7. Allijn IE, Czarny BM, Wang X, Chong SY, Weiler M, da Silva AE. Liposome encapsulated berberine treatment attenuates cardiac dysfunction after myocardial infarction. J Control Release. 2017;247:127-33.

8. Levy Rl, Feinleib M. Risk factors for coronary artery disease and their management. In: Brawnwald E, editor. Heart disease: a textbook of cardiovascular medicine, vol. 2. 2nd ed. Philadelphia: WB Saunders; 1984. p. 1205-34.

9. Mohan IK, Kumar KV, Naidu MU, Khan M, Sundaram C. Protective effect of CardiPro against doxorubicin-induced cardiotoxicity in mice. Phytomedicine. 2006;13:222-9.

10. Calixto JB. Efficacy, safety, quality control, marketing and regulatory guidelines for herbal medicines (phototherapeutic agents). Braz J Med Biol Res. 2000;33:179-89.

11. Rajadurai M, Prince PSM. Comparative effects of Aegle marmelos extract and alpha-tocopherol on serum lipids, lipid peroxides and cardiac enzyme levels in rats with isoproterenol-induced myocardial infarction. Singap Med J. 2005;46:78-81.

12. Amutha P, Pushpa Bharathi N, Vanitha V. Caesalpinia bonducella - a review on pharmacological and phytochemical activity of seeds. Int J Pharm Bio Sci. 2016:7(4):674-80.

13. Okinaka S, Kumagi A, Ebashi S, Sugit H, Mornoi H, Toyokura Y. Serum Creatine phosphokinase activity in progressive muscular dystrophy and nerumuscular disease. Arch Nerunol. 1961;4:250.

14. King J. Practical clinical enzymology. Philadelphia, London: Dvan. Nostranal Co; 1965. p. 363

15. Lamprecht WF, Weisser SH, Heinz F. Determination of creatine phosphate and adenosine triphosphate with creatine kinase. In: Bergmeyer HU, editor. Methods of enzymatic analysis; 1974. p. 1776-8.

16. Katus HA, Remppis A, Looser S. Enzyme linked immunoassay of cardiac troponin $\mathrm{T}$ for the detection of acute myocardial infarction in patients. Mol Cell Cardiol. 1989:21:1349-53.

17. Lowry OH. Rose brough NJ, Farr AL and Randal RJ. Protein measurement with Folin phenol reagent. J. Biolchem. 1951;193:265-75.

18. Giles KW, Mycers A. An improved diphenylamine method for the estimation of deoxyribonucleic acid. Nature. 1965;206:93.

19. Endo Y. A simultaneous estimation method of DNA and RNA by the Orcinol reaction and a study on the reaction mechanism. J BC. 1970;67:629-33.

20. Zak B, Zlatkins A, Boyle AJ. A new method for the determination of serum cholesterol. J Lab clin Med. 1953:14:486.

21. Foster LB, Dunn RT. Stahle reagents for determination of serum triglycerides by a colorimetric Hantzsch condensation method. Clin Chem. 1973:196:338-40.

22. Barlette GR. Phosphorus assay in column chromatography. J.Biolchem. 1959; 234:466-8.

23. Falholt K, Falholt W, Lund B. An easy colorimetric method for routine determination; 1973. p. 21

24. Friedewald WT, Levy RI, Fredrickson DS. Estimation of the concentration of low density lipoprotein cholesterol in plasma without the use of proparative centrifuge. J Clin Chem. 1972;18:499.

25. Bonting SL. Sodium-potassium activated adenosine triphosphatase and cation transport. In: Bittar EE, editor. Membranes and ion transport, vol. 1. London: Wiley Interscience; 1970. p. 257-63.

26. Ohnishi T, Suzuki T, Suzuki Y, Ozawa K. A comparative study of plasma membrane Mg2+ ATPase activities in normal, regenerating and malignant cells. Biochem Biophys Acta. 1962:684:67-74.

27. Hjerten S, Pan H. Purification and characterization of two forms of a low affinity calcium ion ATPase from erythrocyte membranes. Biochem Biophys Acta. 1983;728:281-8. 
28. Nigam PK. Biochemical markers of myocardial injury. Indian J Clin Biochem. 2007;22(1):10-7.

29. Upaganlawar A, Balaraman R. Cardioprotective effects of Lagenaria siceraria fruit juice on isoproterenol-induced myocardial infarction in Wistar rats: a biochemical and Histoarchitecture study. J Young Pharm. 2011;3(4):297-03.

30. Rajadurai M, Prince PSM. Comparative effect of Aegle marmelos extract and a-tocopherol on plasma lipids, lipid peroxides and cardiac marker enzyme levels in rats with isoproterenol-induced myocardial infarction. Sing Med J. 2005;46:72-8.

31. Pekiner B, Ulusu NN, Das-Evcimen N, Sahilli M, Aktan F, Stefek M, Stolc S, Karasu C. The ADIC (antioxidants in diabetes-induced complications) study group in vivo treatment with stobadine prevents lipid peroxidation, protein glycation and calcium overload but does not ameliorate Ca2+ -ATPase activity in heart and liver of streptozotocin-diabetic rats: comparison with vitamin E. Biochim Biophys Acta. 2002;1588:71-8.

\section{Publisher's Note}

Springer Nature remains neutral with regard to jurisdictional claims in published maps and institutional affiliations.

\section{Submit your manuscript to a SpringerOpen ${ }^{\circ}$ journal and benefit from:}

- Convenient online submission

- Rigorous peer review

- Open access: articles freely available online

- High visibility within the field

- Retaining the copyright to your article

Submit your next manuscript at $\boldsymbol{\wedge}$ springeropen.com 